\title{
EHMTI-0051. Prevalence of venous sinus stenosis in pseudotumor cereberi (PTC) using digital subtraction angiography (DSA)
}

\author{
M Hamdy Ibrahim
}

From 4th European Headache and Migraine Trust International Congress: EHMTIC 2014

Copenhagen, Denmark. 18-21 September 2014

\section{Objectives}

To study the prevalence of intracranial venous stenosis in Pseudotumor cereberi patients.

\section{Patients and methods}

Thirty patients diagnosed as PTC according to Dandy criteria. All underwent general and neurological assessment. Radiological assessment included CT scan brain +/- MRI brain without contrast, MRV. All underwent digital subtraction cerebral Angiography (DSA) (venous phase) to confirm the validity of filing gaps seen at the level of MRV.

\section{Results}

MRV brain showed that 24 patients (80\%) showed filling gaps. Digital subtraction cerebral angiography (venous phase) showed 9 patients (30\%) had stenosis in their dural sinuses. MRV showed to be a good screening tool since it had $100 \%$ sensitivity and negative predictive value. However, since it has a moderate specificity $(62 \%)$ with a positive predictive value (PPV) of only $35 \%$, then lesions detected should be confirmed with digital subtraction cerebral angiography (venous phase) particularly those involving the transverse and sigmoid sinus.

\section{Conclusion}

Studying the intracranial venous system in patients with PTC is an important step in understanding the pathophysiology of the disease. Detection of venous sinus stenosis opens the way to a novel therapeutic option for refractory patients like venous sinus stenting.

No conflict of interest.

Neurology, Gulf Medical University GMU and Hospital, Ajman, United Arab Emirates

\section{SpringerOpen $^{\odot}$} provided the original work is properly cited.
Published: 18 September 2014

doi:10.1186/1129-2377-15-S1-C20

Cite this article as: Ibrahim: EHMTI-0051. Prevalence of venous sinus stenosis in pseudotumor cereberi (PTC) using digital subtraction angiography (DSA). The Journal of Headache and Pain 2014 15(Suppl 1):C20.
Submit your manuscript to a SpringerOpen ${ }^{\circ}$ journal and benefit from:

- Convenient online submission

- Rigorous peer review

- Immediate publication on acceptance

- Open access: articles freely available online

- High visibility within the field

- Retaining the copyright to your article

Submit your next manuscript at $\boldsymbol{~ s p r i n g e r o p e n . c o m ~}$ License (http://creativecommons.org/licenses/by/2.0), which permits unrestricted use, distribution, and reproduction in any medium, 